\title{
One Fragment of the Ethnographic Picture of Egypt (Zār Ceremony)
}

\author{
Nino Ejibadze \\ Iv. Javakhishvili Tbilisi State University, Georgia \\ *Corresponding Author: nino.ejibadze@tsu.ge
}

Copyright (C) 2014 Horizon Research Publishing All rights reserved.

\begin{abstract}
The Egyptian Zār ritual is a ceremony that includes different aspects of ethnographic picture; it is possible to study it from the viewpoint of the linguistic, literary, musical, psychological, health and gender issues. The purpose of the ritual is to cure certain diseases by a folk method. It has found its way into Egypt from the south via Sudan. The ritual was regarded by the Government of Egypt as involving certain danger, due to which it was even prohibited. Nevertheless, it functions to the present day, it is performed secretly and strangers' attendance at it is strictly limited. In the article the material collected as a result of fieldwork is presented, namely, some texts are offered, obtained by the author in the 2000s. The report focuses attention on the important details of the Zār practice, such as: 1. types of Zār, 2. Belief in the existence of the so-called Jinn and Sayids, which is the basis for the functioning of Zār, 3. composition of the group performing different types of Zār, 4. Zār diseases and those of medical character, 5. the language of Zār, in which the author of the report has singled out words and expressions that can be considered as the professional slang of Zār, 6. Amulets, 7. Types of musical accompaniment during the performance of the ceremony, as well as various details of the Zār ceremony.
\end{abstract}

Keywords Egypt, Ritual, Spirits, Illness, Amulets, Trance, Texts

In Arabic the word Zār must be of Amharic origin, deriving from the word $j \bar{a} r[1: 289 ; 2: 10-11]$.This lexeme must have found its way into Egypt and Sudan from Ethiopia. However, at the same time, jār (same as yāro, dāro [3:2]; was the main deity of the pantheon of the idolater Kush - the sky god, who then assumed another form and turned into an evil demon. This demon, according to the Ethiopians' belief, lives in rivers, canals and in flowing water in general, and is able to make a person ill. It can be cast out of the body with the help of amulets and incantations [1:289]. Exactly these rituals became the form of the $Z \bar{a} r$ ceremony which is known to us at present and which later on, from the 1860s became established in Egypt through the Sudanese and Ethiopian slave women.

$Z \bar{a} r$ - the ritual which is found in Egypt to the present day implies curing of human beings of a certain group of illnesses by means of a whole series of incantations, odes devoted to jinn and other similar acts.

It should be noted that the specialist literature does not contain exhaustive information about this ritual, despite the fact that Egyptian authors have dedicated two monographs to

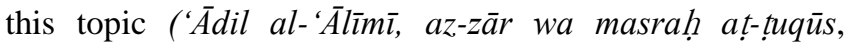
al-Qāhira, 1993 and Fātima al-Mișrī, az-zār, al-Qāhira, 1975). Only fragmentary, sometimes inaccurate, information is offered in several articles published in periodicals at different times. As any manifestation of folklore, the $Z \bar{a} r$ ritual is also characterized by diversity. The present article describes $Z \bar{a} r$ in the form as it appeared at the beginning of the $21^{\text {st }}$ century in the processions performed in the so-called hadāyiq el-ahrām-territory on the outskirts of Cairo, as well as in some regions of northern aṣ-Sa 'ìd (Upper Egypt).

1. Three types of $Z \bar{a} r$ are known in Egypt: Sudanese (as-sudāni), Egyptian (mașri) or aṣ-șa ‘̄idi, i.e. Upper Egyptian and $a b \bar{u} l-g \bar{\imath} t$ or al-gitanìya. Of these the latter two varieties are Egyptian proper, originating in Egypt. These three types differ from one another in nuances, but the main motivation, basis and manner of the ceremony are identical. In the past a fourth type of $Z \bar{a} r$, the so-called rang $\bar{u}$ [4:42] occurred as well.

A distinguishing feature of Sudanese $Z \bar{a} r$ is that together with percussion instruments (which are the main instruments of Zār), tambūra also sounds in it. This is a folk stringed instrument, which is not found in $Z \bar{a} r$ of another type. Therefore Sudanese $Z \bar{a} r$ is sometimes referred to as tambūra too.

In Șa 'ìdi Zār only women participate. In this case some musicians may be male, but it is prohibited for other men to attend such $Z \bar{a} r$, or to perform $Z \bar{a} r$ of this type for a man. $A b \bar{u}$ $l$-git (a settlement of this title is in northwestern Egypt) is one of the varieties of $Z \bar{a} r$, it is of Egyptian origin proper and the most theologized one. Instead of sayids, in $a b \bar{u} l$-git $t$ saints (awliy $\left.\bar{a}^{\prime}\right)$ are addressed and odes dedicated to them are 
performed. In $Z \bar{a} r$ these holy names have the same function as the names of sayids. Participants in this case are mostly men.

$Z \bar{a} r$ can be one-day (yawmīya) and it may also last for 5-7 days. It may be performed by the commission of one particular person (mahsüss), or for several ill persons (al-gama'êya).

2. According to Umm Sāmiḥ (Zār practitioner), there are $Z \bar{a} r$ illnesses and doctor illnesses. If an illness is a doctor's, $Z \bar{a} r$ will not prove useful in its curing, and vice versa - a doctor cannot cure it. $Z \bar{a} r$ illnesses include: nervous disorders, mental illnesses, childlessness, gastric diseases, headaches, spine diseases, limiting movement, etc. Zār also helps a young girl who cannot get married, a woman who constantly miscarries, or gives birth to a dead fetus or sick children.

3. The basis of Zār is the belief in the so-called jinn and sayids - spirits, demons, who really exist and if offended by humans, they can punish the latter by an illness or a misfortune. In the $Z \bar{a} r$ culture the difference between jinn and sayids is that in the Egyptian folk belief jinn are evil demons, whose enraging entails fatal results for a person, sayids are compliant and it is possible to become reconciled with them, hence, the ill person can be cured. Umm Sämih, a $Z \bar{a} r$ practitioner in Cairo (at the time of my contact with her, in 2004, she was 53 years old) confirms the widespread view that the total number of jinn and sayids is 44 . Here is a version of their origin [2:18-19]: at the time of living in the Garden of Eden Biblical Eve had 30 children. When God ordered her to show her children, Eve hid fifteen children outstanding by their mind and appearance, and showed the other fifteen who were inferior by their mental qualities and appearance. God, of course, learned about this and damned the hidden children to be always invisible and live in the dark. The Ethiopians believe that the Zār jinn and sayids are descendants of exactly those children.

Sayids and jinn can get angry with a human being because of a specific behaviour: if a person asserts that demons do not exist, or throws something on the ground in the dark, walks in an impure place, sleeps alone, etc [2:18]. According to another Cairo informer, 'Usāma, jinn can get angry with a person if he/she accidentally hits a jinnee or his child with an object thrown by him/her in the dark (it is regarded that jinn like to be in the dark). Therefore, before a person does something like this, he must utter a warning formula: bismi-l-lähi-r-rahmāni-r-rahìm (in the name of Allah the

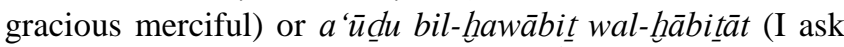
permission from male and female jinn). ${ }^{1}$

The above-mentioned Umm Sämih̆ related that she never liked the song devoted to Christian sayid, as-sitt al-kibira (or

\footnotetext{
${ }^{1}$ Interestingly, in the expression interdental consonants are attested, which, unlike literary Arabic, are uncommon for the dialect. Literary forms usually are uttered in a conversation when citing the Koran. This means that in the imagination of the ordinary people the belief in jinn and the like and the religion are closely related concepts.
}

the great lady, her prototype must be St. Mary). Once, when she was walking alone in the dark she saw a woman clad in black from head to toe. Immediately some power turned her upside down and stuck her with her head in the ground (itzara 't - "I was stuck"). When she came to her senses, the woman in black was no longer visible, but from that day as-sitt al-kibira is her sayid, she regards her song as the most favourite ode now and often performs it in order to make her sayid relent.

The $Z \bar{a} r$ practitioners believe that in the world of spirits there is a certain hierarchy, they have families as well. E.g. as-sultān al-'ahmar - the red sultan and as-sitt al-kibìra are husband and wife and head this hierarchy. At the same time, patriarchate characteristic of the Muslim world is violated in sayids - as-sitt al-kibira is a more powerful spirit than her husband. Their daughter, little ruküšs is a jinnee and her anger entails death. Each jinnee and sayid has certain favourite objects or offering. For example, a red cloak, red candles and a red hen or a cock must be offered to the red sultan. Among

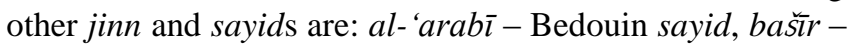
Ethiopian spirit, aș-sinn - i.e. Chinese, dāyir an-nașāri Christian said, al-baḥareya - i.e. of the sea, a female sayid, having the appearance of a fish, inhabiting water; $a b \bar{u}$ rawayyi of fragrance, doctor sayid ḥākimbā ăa - pasha doctor, lüliya, bašs's sister, who asks for colour clothing, intended for wedding, safina - literally, "a ship", is a spirit of the sea, pairs of spirits: sitt wasiddi, i.e. lady and gentleman. It is noteworthy that first the lady is mentioned; same fāru $\bar{k}$ and his wife, the same king and queen, twins hārūt wa mārūt angels known from the Koran [2:102], who assumed the form of magician sayids [al-Qur'ān, 2:101]; al-qärina the jinnee who is at enmity with new-born children, kills or eats them, $a b \bar{u}$ l-gind $\bar{l}$, to whom a grey lamb must be sacrificed, an-nār $r \bar{l}$ - fiery, a person obsessed by this said during Zār holds two sheets of paper set on fire till they burn up, amir al-hăgg - king of pilgrims, - bandūh, who demands from the ill person eating raw sheep testicles, al-gamal - a possessed person must whip himself till he loses consciousness, etc. The names of these sayids have been obtained from the Egyptian and Sudanese informers in different regions of Egypt, some of them are also attested in the specialist literature $[3 ; 5: 58-59 ; 6: 89-108 ; 7: 16-20]$.

4. The performer of the $Z \bar{a} r$ ceremony is called kódiya. More often ködiyas are women, but there are male ködiyas as well. Kódiya is also referred to as sheikhess (or sheikh, if it is a man). This is a person who inherits his profession and has adopted it in childhood naturally. Kódiyas often boast of their Sudanese origin and of the fact that they were brought up in a family imbued with the $Z \bar{a} r$ traditions, which adds special convincingness to their professionalism. Kódiyas often call themselves daughters of fragrances (banāt el-buhūr), as fragrance is an inseparable element of Zār. A kodiya is a person who has direct connection with sayids and jinn, she sees and talks to them. A person is consecrated kōdiya as a result of a special ceremony, called rabt el-hizām 
"girding". At this time the person wishing to become a kódiya takes a certain examination, sings odes dedicated to all sayids and performs every detail, envisaged by the $Z \bar{a} r$ ceremony. Experienced women watch if everything has been performed properly, and then put a special girdle around the waist of the examinee, which means that from that moment this person has become a ködiya.

The $Z \bar{a} r$ payment and offering, asked by spirits through the kōdiya, usually depends on the material state of the family. This may be a hen or a dove and even a camel. After the kōdiya appoints the date of $Z \bar{a} r$, the family of the ill person begins to prepare for $Z \bar{a} r$.

The kódiya is assisted in the performance of $Z \bar{a} r$ by a group. It may consist of the following persons: 1. odiya - the main assistant, who knows by heart every ode in honour of all spirits, and may take upon herself the entire process, but unlike the kódiya, she cannot get into contact with jinn and sayids. An ódiya is often a maiden who herself has an angered sayid, or a son with homosexual inclinations, or a hermaphrodite. 2. sanjaq - in Sudanese Zār the performer of ceremonies. Like an odiya, a sanjaq cannot get in touch with spirits. 3. The so-called ad-daqqaqīn - in Egyptian $Z \bar{a} r$, in which men do not participate, these women beat percussion instruments with iron sticks. Beats must be strong in order to have a more powerful impact on the patient. I have witnessed how the leather, stretched over the boards, was torn by strong beats. 4. satri - mangoura player. Mangoura represents goat hooves strung on leather, which are fastened to a thick leather belt. A player puts this belt around the waist and begins to move in rhythm with the movement of the hips. A sound resembling jingling is produced. 5. btā' tambüra "țambūra man", player of the stringed instrument țambüra.

5. From time immemorial amulets had great significance and were popular in the oriental world. In Egypt, along with amulets, widespread since the Ancient Egyptian period, surviving to the present day there are also Zār amulets proper.

A person who has lived in Egypt will have undoubtedly noticed that Egyptians seldom wear silver jewellery. They like gold. For an Egyptian woman gold is a means of capital investment. As regards $Z \bar{a} r$ amulets, they are mostly made of silver, as is accepted in the tradition of some other peoples. The following are regarded as $Z \bar{a} r$ amulets: bracelets, khulkhals (bracelet-like ornaments to be worn on shins), pendants, arm ornaments [5:58-59]. As Schienerl [7:16-20] notes, only hand-made amulets, and not stamped ones, are valuable and "fulfill their function" in Egypt.

Coloured, garish beads, scraps of fabric also serve as amulets, which are used for decoration of the Zār instrument with the motif that coloured objects attract spirits and dispose them favourably toward humans.

6. The aim of the $Z \bar{a} r$ ceremony is to put the ill person into a trance. If this is achieved, the sayid will temporarily enter his body. Ahmad Taha (about 55 years old, he did not know his exact age), narrated that at that time the patient may begin to speak in a strange, unusual voice. This will be the sayid speaking through the ill person. The trance will be followed by curing.

If a person once resorted to $Z \bar{a} r$, he is obliged to "become enrolled in the guild" of $Z \bar{a} r$ and to resort again and again to the so-called karama, a ritual of a lower rank than Zār for mollifying spirits, during which only food and different objects are offered to sayids, and to order Zār performance [2:17] for himself repeatedly. Otherwise, spirits will get angry with him.

In the period preceding $Z \bar{a} r$, and especially in the $Z \bar{a} r$ period, everybody shows affection towards the sick person and tries not to offend him/her. This is necessary for curing. $Z \bar{a} r$ requires from a family such great expenses and efforts that, as Kenyon's one informer notes, preparation for Zār is worse than preparation for a wedding [6:89-108]. At that time close relatives and friends of the family are invited, who are treated to sweets, nuts and various dishes. In their turn, these visitors, who are called habayyib (close friends) or $\check{s} u h \bar{u} d$ (witnesses) indulge the Zār patient, are affectionate and fulfill his/her every caprice.

The ritual begins with the so-called fätiḥa, i.e. opening address, in which some researchers see a reflection of the Fatiha (opening sura) of the Koran. Umm Sämiḥ uttered the following fätiha:

"sīd ibrāhīm ad-dasū'i, sīd 'izz ər-riggāl, al-hiḍ̂r war-riyyās wal-mursi abul-'abbās yiḩdu d-dub̧ān wyiddūki l-'āfiyya wal-burhān biḥa" gāhid an-nabī 'alē ṣ-ṣalāt wa afụal əs-salām. bēt əz-zār, bēt māmmā watbā'u, rūm nagdi watbā'u, yūsef watbā' $u$, abu danfa watbā' $u$, al-wazīr watbā'u, al-'arabi watbā'u, as-sulțān əl-aḥmar, dīr ən-nașāri, bēt al-ḥabaš, as-sittāt: șādēyya hānim, al-baharēyya.

ana 'arīt al-fātiḥa bil-amāna."

"Sayid ibrahim ad-dasuqi, sayid "izz ar-rigal, al-khidr and riyas and al-mursi abu 1-'abbas will accept fume and will give you good health and harmony, by the right granted by the prophet, to whom we pray and devote the best greetings. The Zar house is the house of mamma and his followers, rum nagdi and his followers, yusuf and his followers, abu danfa and his followers, al-gindar and his followers, al-wazir and his followers, al-'arabi and his followers, the red sultan and his followers, dair an-nasari, the house of the Ethiopians, of ladies - sadia hanim and al-baharea. ${ }^{2}$

So, I have uttered the fătiha with peace!"

This is followed by odes dedicated to one or several sayids, performed by the kodiya and other members of the group, with very loud accompaniment of percussion instruments (sometimes together with tambüra). These are songs intended to win the disposition of sayids. E.g. Umm Sämiḥ in one of her odes to al-'arabi sang (the hyphen at the beginning denotes the syntagma of the members of the

\footnotetext{
${ }^{2}$ Of these sayids, e.g. al-Hiḍr is St. George, whereas imam ibrāhīm ad-dasūqi and some other names are known from the Islamic tradition, mursī 'abū $l$ - 'abbās mosque is a famous mosque in Alexandria, etc.
} 
group):

șallīt fil-ḥarām 'ala l-bēt In the time of trouble I prayed to the house (implying the house of sayids, i.e. kin)

-wṣallu 'ala l-'arabi muhammad. and you pray to al-'arabī, Muhammad,

ya 'arabi ya zīn, ya kaḥīl al-'ēn, You, Arab (in this way the Arabs themselves refer to Bedouins

and al-'arabī is a Bedouin sayid, with eyes decorated with kuhl,

- wṣallu 'ala 1-'arabi muhammad. and you pray to al-'arabī, Muhammad,

ya nūr in-nūr, ya bahēyya n-nūr, Light, oh, light, endowed with beauty,

- wṣallu 'ala l-'arabi muhammad. and you pray to al-'arabī, Muhammad,

da 'albi tawalla' biziyārt or-rasūl, My heart kindled by the sight of the prophet,

- wṣallu 'ala l-'arabi muhammad. and you pray to al-'arabī, Muhammad,

ya 'arabi 'urubān, ya halāwa l-hilalēyya. You, Arab, Uruban (diminutive from "Arab", like the moon, sweet.

da zāyir nabīna mḥammad elli yizayyin əl-kufēyya, Seer of the Lord Muhammad,which decorates with kufeya ,

ya 'arabi 'urubān, ya ḥalāwa l-hilalēyya. You, Arab, Uruban, like the moon, sweet.

ya šeyih əl-'abīla ya 'arabi, Chieftain of the tribe, you, Arab,

da zāyir nabīna l-'abari, Seer of the Lord, al-'arabī, ya sīdi, waruddu 'alēyya. My Lord, and answer me.

- ya šeyih ol-'abīla ya 'arabi, Chieftain of the tribe, you, Arab,

da zāyir nabīna l-'abari, Seer of the Lord, al-'arabī, da 'awāyidak sanawēyya ya 'arabi, Your celebrations are annual, you, Arab,

ya šeyih əl-'abīla ya 'arabi, Chieftain of the tribe, you, Arab,

zāyir nabīna ya badawi. Seer of the Lord, you Bedouin, etc.

The rhythm of percussion instruments is more and more accelerated, then each musician approaches the ill person, who is dancing. Usually, these are simple, symmetric movements. The musicians beat percussion instruments with iron sticks at the ears of the dancing patient. Then the rhythm is violated and each musician plays with his own rhythm. Exactly at this time the patient must fall into a trance, which is not so difficult taking into account the above-mentioned and bearing in mind the belief of these people in $Z \bar{a} r$.

At the same time the bird or animal for slaughter is killed. If this is a bird, it is slaughtered exactly above the head of the ill person. If it is larger in size, it is slaughtered so that blood is not spilt and the patient is bathed in this blood. Biyā da 'Ahmad Tilib (48-years-old in 2005) narrates that the blood-stained clothes must not be changed. After $Z \bar{a} r$ the sick person dressed in these clothes is locked for several days - five, seven days, as the kōdiya orders [8:5]. No one is admitted to him/her except one nurse, who gives him food silently. After the expiration of this term $Z \bar{a} r$ is regarded to be finished. The blood-stained clothes are kept specially, as precious objects.

Performance of $Z \bar{a} r$ is prohibited in the holy month of Ramadan. As Al-magrabi noted, at that time, as well as during other religious feasts, $Z \bar{a} r$ is not performed, in the holy days "we leave spirits alone, and we stay to ourselves" [8:17]. If the family is in mourning or some other misfortune has befallen it, $Z \bar{a} r$ is not performed in that case either [3:8-9].

The question arises naturally as to whether $Z \bar{a} r$ has any obvious results. It is attested that sometimes $Z \bar{a} r$ indeed gives certain relief to the ill person. Behman in the work [3:23-24] notes correctly that $Z \bar{a} r$ is effective in two cases: 1 . if an illness is of psychological character. By way of illustration the author cites the story of a girl whose engagement failed several times. This made her think that sayids were angry with her, which led her to apathy. In a similar situation several procedures of $Z \bar{a} r$ proved sufficient for curing the girl's mental disorder. 2. When a disease is organic and its symptoms are expressed by pain. The trance as a result of $Z \bar{a} r$ may cause hypnotic anesthesia and temporarily alleviate pain [3:24], which may, by the way, ultimately even entail fatal results, as due to artificial suppressing of pain the patient does not consult a doctor and the illness grows progressively worse.

7. In Egypt Zār is mostly performed in the native Egyptian dialect of the local population, but the hymns to some sayids are performed in another language. 'Abd al-Hamìd Yünis in the Folklore Dictionary [1:289] notes that this is the " $Z \bar{a} r$ language", which is regarded as the secret language and no one knows it except the $Z \bar{a} r$ group. The $Z \bar{a} r$ practitioners known to the present author avoided talking on this topic and refused to explain some phrases which were uncertain from the position of Arabic.

Even when $Z \bar{a} r$ is performed in Arabic, in the Egyptian dialect, there are certain expressions which are unknown to those who are not familiar with this ritual. E.g. bēt az-zār: $b \bar{e} t$ (Arab. house), as a term, in the Zār tradition denotes the entire Zār ceremony. The phrase: bèt ez-zār talāt adwār (lit. there are three floors in the $Z \bar{a} r$ house) - in the $Z \bar{a} r$ ceremony three types are singled out (i.e. there are three different types of $Z \bar{a} r$ [9:59-60]. ithaggab/ithajjab: it is derived from the word higa $\bar{a} b / h i j \bar{a} b$ (in $Z \bar{a} r$ this is a variety of amulet) and denotes: "acquired an amulet, began to wear an amulet" [9:72]. Usually in the Egyptian dialect this word denotes that a woman began to wear a head-scarf (hejab), which is a certain rule with Muslim women; hadrra: a regular (as a rule, weekly) variety of $Z \bar{a} r$ [9:74] Usually, this word in Arabic means "to attend", etc. 


\section{REFERENCES}

[1] 'Abd al-Ḥamīd Yūnis (1983), mu 'jamu l-fulklūr, Lubnān (in Arabic).

[2] Fāṭima al-Miṣrī (1975), az-zār, al-Qāhira (in Arabic).

[3] F. Behman (1953), The Zar in Egypt, unpublished, project for the Bachelor's degree, Cairo

[4] 'Ādil al-'Ālīmī (1993), az-zār wa masraḥ aț-tuqūs, al-Qāhira (in Arabic).

[5] S. Weeks (1984), Silver Zar Amulets, Cairo Today, February.
[6] S. M. Kenyon (1999), The Case of the Butcher's Wife, in: Spirit Possession, Modernity and Power in Africa.

[7] P.W. Schienerl (1983), Amulets in Modern Egypt, Ornament, 6 , no 4.

[8] N. Ejibadze (2008), Egyptian Arabic, Texts, Dictionary, Tbilisi (in Arabic).

[9] N. Ejibadze (2010), The Zar Ritual in Egypt, Tbilisi (in Georgian). 